\title{
Drug shortages in anesthesia and perioperative medicine: Canada needs a better supply system
}

\author{
Richard Hall, MD • Richard Chisholm, MD • \\ Davy Cheng, MD • Michael Murphy, MD • \\ David Campbell, MD
}

Received: 16 March 2012/ Accepted: 28 March 2012/Published online: 17 April 2012

(c) Canadian Anesthesiologists' Society 2012

On February 15, 2012, Sandoz Canada notified pharmacies across Canada that it would be reducing the manufacturing capacity of its pharmaceutical manufacturing plant in Boucherville, Québec while undertaking intensified remediation efforts. $^{\mathrm{A}, \mathrm{B}}$ The company announced that it was taking these steps as a result of an inspection by the United States Food and Drug Administration (FDA) and a warning letter sent by the FDA in November 2011. Sandoz Canada also served notice that it would be discontinuing certain (unspecified) intravenous products in conjunction with this closure. $^{\mathrm{C}}$ The anticipated duration of the reduction in services is unknown, but it could likely be more than 18 months. On March 4, 2012, a fire in the boiler room of the Boucherville plant further reduced the plant capacity, and as a result, injectable drugs were being produced in limited amounts. ${ }^{D}$ Sandoz Canada supplies $80 \%$ of the market for generic injectable drugs in Canada, including many used in

\section{R. Hall, MD}

Dalhousie University and the Queen Elizabeth II Health

Sciences Centre, Halifax, NS, Canada

R. Chisholm, MD

Canadian Anesthesiologists' Society, Toronto, ON, Canada

D. Cheng, MD

University of Western Ontario, London, ON, Canada

\section{Murphy, MD}

University of Alberta, Edmonton, AB, Canada

D. Campbell, MD

University of Saskatchewan, Saskatoon, SK, Canada

R. Hall, MD ( $\varangle)$

Halifax Infirmary, Room 5452, 1796 Summer St.,

Halifax, NS B3H 3A7, Canada

e-mail: rihall@dal.ca the delivery of anesthesia, critical care, and pain medicine. As a consequence of the tight supply chain between the manufacturer and hospital pharmacies, elective surgery cancellations were being reported almost immediately following the announcement.

Physicians across Canada are stunned by this sequence of events and its considerable negative impact on the delivery of anesthesia and critical care medicine in Canada. Several factors must be considered to understand what has led to these events. First, as regards the actions by Sandoz, according to the news release cited above, Sandoz Canada had been duly notified of the FDA report and its recommendation of November 2011. Despite receiving this notification, Sandoz did not notify Canadian doctors of its decision to reduce drug production prior to the actual rampdown of production at the Boucherville plant. Even if we consider the time the company needed to evaluate the intensified remediation measures required at the Boucherville plant, the time lag suggests that alternative suppliers could have been notified and drug production could have been augmented at other facilities. Apparently, these steps could not be taken because the key stakeholders were not informed of the decision to reduce drug production until February 2012. While this decision may have made good business sense (as it served to protect the market share until the very last moment), it has exposed the Canadian population to the vagaries of an overly tight drug supply chain

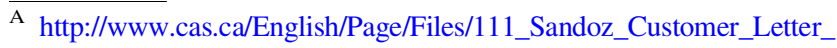
FINAL_2012_02_15.pdf (accessed March 2012).

B http://www.cas.ca/English/Page/Files/111_Sandoz_Customer_Letter_ FINAL_2012_02_17.pdf (accessed March 2012).

C http://www.sandoz.ca/assets/content/en/forms/pdf/Boucherville_ Supply_PR_EN_final_29_02_2012.pdf (accessed March 2012).

D http://www.sandoz.ca/site/en/media_room/news/120306.shtml (accessed March 2012).
} 
with certain limitations in regulatory oversight. It is surprising that Sandoz Canada could not have developed some form of contingency plan much earlier to enable the distribution of critical drugs to continue without interruption. As Sandoz Canada is the sole source supplier of many anesthesia and critical care drugs in Canada (e.g., morphine, furosemide, rocuronium), it is our view that, prior to taking action to reduce drug production, it was the company's obligation to ensure that the supply of these drugs continued and appropriate arrangements were implemented to secure an adequate supply of critical drugs until renovations to the Boucherville plant were completed.

\section{As regards Health Canada}

Health Canada is our government regulatory body responsible for the safety and licensing of drugs in Canada. The Federal Government has not been proactive during the current drug shortages crisis, as revealed by several important observations:

1. Seeing as Health Canada became aware of the FDA warning letter dated November 2011, why would Health Canada not have been notified by Sandoz prior to February 2012 about the impending slowdown in production at the Boucherville manufacturing plant? It is regrettable that there is no current mechanism to prevent such catastrophes from occurring (see the Federal Ministry of Health response to concerns of potential drug shortages raised by the Canadian Anesthesiologists' Society). ${ }^{\mathrm{E}}$ Immediate action is warranted to implement safeguards to prevent the reoccurrence of such events. It is clearly problematic to leave the process of notification of impending drug shortages at the discretion of the pharmaceutical companies. ${ }^{\mathrm{F}}$

2. Do the standards for pharmaceutical manufacturing in Canada differ from those in the United States such that it was deemed acceptable for the Boucherville plant to continue producing drugs under possibly substandard conditions? The answer to this question is more complex. The FDA had its own concerns. Apparently, Health Canada had also inspected the plant and, as a result, required certain process changes to be implemented. Regrettably, these changes appear to have been insufficient from the standpoint of the FDA. To some extent, this may simply have boiled down to a lack of resources for appropriate plant inspections or

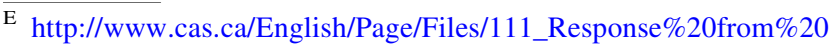
Aglukkaq.pdf (accessed March 2012).

F http://www.cbc.ca/news/health/story/2011/10/17/drug-shortagescompanies-plans.html (accessed March 2012).
}

inspector training on the part of Health Canada, a matter of concern affecting the manufacture of not only injectable drugs produced for anesthesia but also drugs in general.

3. Seeing as Sandoz is the sole source supplier for many critical drugs in Canada, was there a contingency plan to allow for drugs to be imported in the event of a shortfall in production? Given our current understanding of the Federal government's response to this crisis, the answer to this concern is a definite "NO".

The issue of drug shortages is not new to the Government of Canada, for example, shortages of propofol were identified in 2011. Oncologists, psychiatrists, and infectious disease specialists have been dealing with important drug shortages for some time, consequently, Health Canada has been aware of this growing critical problem. The issue may have been partially masked (at considerable cost in time and money) by the diligent work of many pharmacists to obtain medications from alternate sources. Perhaps it has taken a shortage of this magnitude to unmask the difficulties they have been experiencing for some time. ${ }^{\mathrm{G}}$

Despite the ongoing issues of pharmaceutical supply over many years, it appears that Health Canada has not deemed it necessary to develop a national contingency plan to deal with drug shortages. To date, no alternative plan has been presented to the Canadian Anesthesiologists' Society. This is despite written communication from the Society to the Federal Minister of Health concerning what has now evolved into a national issue of patient safety and quality of care that requires urgent action. We point out that, in 2011, the FDA identified and acted on the severity of drug shortages and the related impact on patient care in the United States. ${ }^{\mathrm{H}}$ The growing severity of drug shortages led to the release of an Executive Order by United States President Barack Obama to ensure that the United States public is protected against shortages of prescription drugs. I It is unclear why similar actions have yet to take place in Canada. There are several nuances to this issue that bear consideration. For example, in the United States, a "grey market" exists where drugs in short supply can be obtained $^{\mathrm{J}}$ (often at increased cost). ${ }^{\mathrm{K}}$ As Canada will now have to import drugs to meet market requirements, it is important to know the regulatory processes that Health Canada will

\footnotetext{
$\overline{\mathrm{G}}$ http://www.pharmacists.ca/cpha-ca/assets/File/cpha-on-the-issues/ DrugShortagesReport.pdf (accessed March 2012).

${ }^{\mathrm{H}}$ http://www.fda.gov/downloads/AboutFDA/ReportsManualsForms/ Reports/UCM277755.pdf (accessed March 2012).

${ }^{\text {I }}$ http://www.whitehouse.gov/the-press-office/2011/10/31/executiveorder-reducing-prescription-drug-shortages (accessed March 2012).

J https://www.premierinc.com/about/news/11-aug/Gray-Market/GrayMarket-Analysis-08152011.pdf (accessed March 2012).

${ }^{K}$ www.cmaj.ca/content/184/2/E119.full (accessed March 2012).
} 
implement to ensure the quality of imported drugs, including issues of sterility, drug labelling, and drug formulation. Can Health Canada implement these processes in an accelerated fashion, and at what cost? The Federal Minister of Health has commented that essential drug procurement can be accelerated without putting Canadians at risk. ${ }^{\mathrm{L}}$ This being the case, it brings into question why an expedited review process for patented drug applications was not implemented prior to the current drug shortage. With a drug shortage of this magnitude, both national and international in scope, it is unlikely that any single manufacturer will have the capability to increase its production lines to accommodate immediate and short-term needs. In our view, this situation could likely endure for as long as 12-18 months.

At the provincial level, this drug shortage crisis exposes the complexity of prescription drug handling in our health care system. Health Canada regulates the drug approval and licensing processes; however, it is the responsibility of the provinces to fund the delivery of health care to their residents, and it is the responsibility of hospitals and health care regions to select which drugs, technologies, and procedures will be delivered. The reason that the current drug shortage has resulted in the cancellation of surgery in some provinces lies in the vulnerability of having drug supply from sole source distributors.

The inexorable pressure to implement lean processes and cost containment has resulted in most provinces adopting a single-source buyer model in order to contain drug costs. Three of these buying groups supply drugs to more than $90 \%$ of the hospitals in Canada. ${ }^{\mathrm{M}}$ As a result, there is limited ability to procure drugs in short supply at the local level should the "sole source" distributor not be able to deliver. This concern is compounded by the fact that most distributors and pharmacies are working on "justin-time" delivery models to cut inventory costs. This has meant that no stockpiles exist, leading to immediate consequences of the Sandoz Canada decision.

Lean drug production and supply has become a surrogate for "best price". While we appreciate the current fiscal realities facing health care, it appears that the implementation of these cost reduction strategies has come at the expense of alternative strategies to ensure the continuous delivery of critical medications necessary for the delivery of modern anesthesia and critical care. Parenthetically, most drugs employed in anesthesia are relatively

\footnotetext{
$\overline{\mathrm{L}}$ http://www.theglobeandmail.com/news/politics/government-fasttracks-approvals-for-vital-drugs/article2370988/ (accessed March 2012).

M Letter to The Deputy Minister of Health, Dated 2 March 2012, from MEDBUY (Richard Jones) and SigmaSanté (Jean-François Bussières).
}

inexpensive, and one wonders what actual cost savings have been achieved by adhering to lean production/supply methodologies.

The extent to which the current drug shortage will impact patient care in Canada is unknown, but we offer the following for consideration. It is likely that rationalization and prioritization will occur as the supply of drugs becomes more critical and results in extensive surgical cancellations. The provincial and federal governments will be required to develop contingency plans to ensure a continuous supply of pharmaceuticals for the benefit of all Canadians. There will almost certainly be surgical cancellations. At best, this will constitute an inconvenience and a growth of surgery wait lists, and at worst, patients on prolonged surgical wait lists may die.

We encourage all anesthesiologists to enhance ongoing collaboration with their hospital pharmacies to develop transparent guidelines for the allocation of drug resources in limited supply. For example, one might envision a prioritization scheme wherein life-threatening emergencies would receive first priority (historical data should be included regarding the quantity and types of drugs to stockpile to supply this need), followed by prioritizing elective surgeries based on life- or limb-threatening disease, and then by surgery with (an already) long wait list, and so forth. In addition, agents provided in large volume (e.g., fentanyl supplied in $20 \mathrm{~mL}$ vials) may be divided (under the appropriate sterile conditions) into smaller aliquots of prefilled syringes for immediate use, or perhaps alternative agents (e.g., sufentanil) in greater supply may be employed. Physician leaders must be actively engaged at the hospital level and with health regions and provincial and federal governments in modelling the reasons for disruptions in pharmaceutical supply and in designing contingency plans to address these issues (as in the recent management of the H1N1 pandemic and the blood shortage crisis).

It is essential that steps be taken immediately to remedy the current shortage of drugs - not only in anesthesia and critical care but also in therapeutic areas, such as oncology and infectious diseases. Such steps might include legislation requiring manufacturers to provide adequate notification to federal and provincial authorities of any impending shortage, so that stockpiling and contingency planning can occur. Penalties should be levied if such steps do not occur. In the event of an unpredictable disaster or interruption in supply, there should be contingency supplies available for drugs deemed essential. While pharmaceutical companies have the right to determine which products they develop and manufacture, there are certain critical drugs that may not be profitable (e.g., morphine, ephedrine, norepinephrine) but are essential for the health of Canadians. Policy remedies to ensure an uninterrupted supply of all essential medications are easily imagined. 
Further, it is imperative that the large buying groups no longer be permitted to award "sole source" contracts for critical drugs, effectively eliminating any competitive opportunity for smaller companies to remain in the marketplace. By necessity, these companies are now going to supply a proportion of the market share, and in our view, they should be encouraged to do so and continue to do so. A provision should be put in place to provide incentives for small companies to continue to compete in the Canadian marketplace and to eliminate "sole source" provision of critical drugs, however defined.

In conclusion, when it comes to reviewing the ability of Canada's health care system to deliver health care to Canadians effectively, a number of important issues require reconsideration, including the accountability of the pharmaceutical industry and large buying groups to ensure continuous drug delivery, the practice of just-in-time delivery, the role of pharmaceutical contingency planning and drug stockpiling, and sole source procurement practices. In our view, this disaster was entirely preventable. Canadians merit better management of our drug supply system.

\section{Pénurie de médicaments en anesthésie et médecine périopératoire: le Canada a besoin d'un meilleur système d'approvisionnement}

Le 15 février 2012, Sandoz Canada a averti les pharmacies de l'ensemble du Canada qu'elle réduirait la capacité de fabrication de son usine pharmaceutique de Boucherville, au Québec, tout en intensifiant ses efforts pour remédier à la situation. ${ }^{\text {A,B }}$ La société a annoncé qu'elle prenait ces mesures à la suite d'une inspection de la Food and Drug Administration (FDA) des États-Unis et d'une lettre d'avertissement envoyée par la FDA en novembre 2011. Sandoz Canada a également publié un communiqué annonçant qu'elle interromprait la production d'un certain nombre de produits intraveineux (non précisés) en rapport avec cette fermeture. ${ }^{\mathrm{C}}$ La durée prévue de la réduction des services est inconnue, mais elle pourrait probablement être supérieure à 18 mois. Le 4 mars 2012, un incendie dans une chaufferie de l'usine de Boucherville a réduit encore

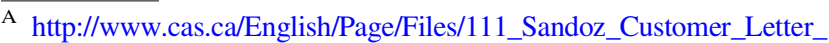
FINAL_2012_02_15.pdf (accessed March 2012).

B http://www.cas.ca/English/Page/Files/111_Sandoz_Customer_Letter_ FINAL_2012_02_17.pdf (accessed March 2012).

C http://www.sandoz.ca/assets/content/en/forms/pdf/Boucherville_ Supply_PR_EN_final_29_02_2012.pdf (accessed March 2012).
}

davantage la capacité de l'usine et en conséquence, des médicaments injectables ont été produits en quantités encore plus limitées. ${ }^{\mathrm{D}}$ Sandoz Canada fournit $80 \%$ des médicaments injectables génériques du marché canadien, y compris de nombreux produits utilisés en anesthésie, aux soins intensifs et pour le traitement de la douleur. Du fait de la courte chaîne d'approvisionnement entre le fabricant et les pharmacies d'hôpitaux, des annulations de chirurgie programmée ont été signalées presque immédiatement après cette annonce.

Dans tout le Canada, les médecins sont stupéfaits par cette suite d'événements et son impact négatif considérable sur la réalisation des anesthésies et la poursuite de soins intensifs au pays. Plusieurs facteurs doivent être envisagés pour comprendre ce qui a conduit à de tels événements. Tout d'abord, pour ce qui concerne les actions de Sandoz, et d'après le communiqué de presse cité plus haut, Sandoz Canada a été dûment informée du rapport de la FDA et de sa recommandation de novembre 2011. Bien qu'ayant reçu cet avis, Sandoz n'a pas averti les médecins canadiens de sa décision de réduire la production de médicaments avant de mettre cette décision en œuvre à l'usine de Boucherville. Même si nous prenons en compte le temps qu'il a fallu à la société pour évaluer les mesures correctrices renforcées qui étaient nécessaires à l'usine de Boucherville, le délai laisse penser que d'autres fournisseurs auraient pu être avertis et que la production de médicaments aurait pu être augmentée dans d'autres usines. Ces mesures n'ont apparemment pas pu être prises parce que les principaux intervenants n'ont pas été informés avant février 2012 de la décision de réduire la production de médicaments. Bien que cette décision puisse être vue comme une bonne stratégie d'affaires (dans la mesure où elle vise à protéger la part de marché jusqu'à la toute dernière minute), elle a exposé la population canadienne aux caprices d'une chaîne d'approvisionnement beaucoup trop tendue avec certaines lacunes en matière de supervision réglementaire. Il est étonnant que Sandoz Canada n'ait pas pu élaborer beaucoup plus tôt une forme de plan de secours qui aurait permis la poursuite sans interruption de la distribution de médicaments essentiels. Considérant que Sandoz Canada est le seul fournisseur de nombreux médicaments d'anesthésie et de soins intensifs au Canada (morphine, furosémide, rocuronium, par exemple), nous pensons que la société avait l'obligation de s'assurer que l'approvisionnement serait maintenu pour ces médicaments et de prendre les mesures nécessaires - avant de décider une réduction de la production de médicaments - qu'un approvisionnement suffisant de médicaments essentiels

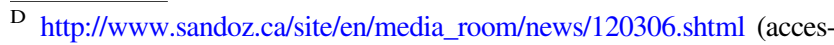
sed March 2012).
} 
serait assuré jusqu'à la fin des travaux de rénovation de l'usine de Boucherville.

\section{Concernant Santé Canada}

Santé Canada est notre organisme réglementaire gouvernemental chargé de veiller à l'innocuité des médicaments et à autoriser leur vente au Canada. Le gouvernement fédéral n'a pas été proactif au cours de la crise actuelle de pénurie de médicaments, comme le révèlent plusieurs observations importantes:

1. Sachant que Santé Canada a été informé de la lettre d'avertissement de la FDA datant de novembre 2011, pourquoi Santé Canada n'aurait-il pas été averti par Sandoz avant février 2012 du ralentissement imminent de la production de l'usine de fabrication de Boucherville? Il est regrettable de constater qu'il n'existe aucun mécanisme pour empêcher la survenue de telles catastrophes (voir la réponse du ministre fédéral de la santé à la préoccupation soulevée par la Société canadienne des anesthésiologistes d'une possible pénurie de médicaments). ${ }^{\mathrm{E}}$ Une action immédiate est justifiée pour mettre en place des mesures de précaution afin d'éviter la répétition de tels événements. Il est manifestement problématique de laisser à la discrétion des sociétés pharmaceutiques le processus de notification d'une pénurie imminente de médicaments. ${ }^{\mathrm{F}}$

2. Les normes canadiennes de fabrication des médicaments sont-elles si différentes de celle des États-Unis qu'il a été jugé acceptable de laisser l'usine de Boucherville continuer à produire des médicaments dans des conditions possiblement insatisfaisantes? La réponse à cette question est plus complexe. La FDA a son propre cahier des charges. Santé Canada avait également inspecté l'usine et avait demandé, à la suite de cette inspection, que certaines modifications de procédure soient mises en œuvre. Malheureusement, ces changements semblent avoir été insuffisants du point de vue de la FDA. Dans une certaine mesure, cela pourrait simplement se résumer à un manque de ressources chez Santé Canada pour des inspections appropriées des usines ou d'un manque de formation de l'inspecteur, un sujet de préoccupation non seulement pour les médicaments injectables destinés à l'anesthésie, mais aussi plus généralement pour l'ensemble des médicaments.

\footnotetext{
$\overline{\mathrm{E}}$ http://www.cas.ca/English/Page/Files/111_Response\%20from\%20 Aglukkaq.pdf (accessed March 2012).

F http://www.cbc.ca/news/health/story/2011/10/17/drug-shortagescompanies-plans.html (accessed March 2012).
}

3. Sachant que Sandoz est le seul fournisseur de nombreux médicaments essentiels au Canada, existait-il un plan d'intervention permettant l'importation de médicaments dans le cas d'une insuffisance de production? Compte tenu de ce que nous savons de la réponse du gouvernement fédéral à cette crise, la réponse à cette question est manifestement « NON ».

Le problème de la pénurie de médicaments n'est pas nouveau pour le gouvernement canadien puisqu'il y avait eu, par exemple, une pénurie de propofol en 2011. Les oncologues, les psychiatres et les spécialistes des maladies infectieuses sont confrontés depuis quelques temps à d'importantes pénuries de médicaments si bien que Santé Canada était conscient de la gravité de ce problème croissant. Ce problème peut avoir été partiellement masqué (avec un coût considérable, en temps et en argent) par le travail diligent de nombreux pharmaciens cherchant à obtenir les médicaments à partir d'autres sources. Il fallait peut-être une pénurie de cette ampleur pour mettre en lumière les difficultés auxquelles ils sont confrontés depuis quelque temps. $^{\mathrm{G}}$

En dépit des problèmes continuels d'approvisionnement en médicaments depuis plusieurs années, il semble que Santé Canada n'a pas jugé nécessaire d'élaborer un plan d'intervention national pour faire face sans à une pénurie de médicaments. À ce jour, aucun plan de remplacement n'a été présenté à la Société canadienne des anesthésiologistes. Et cela, malgré des échanges de lettres entre la Société et le ministre fédéral de la santé à propos de ce qui est maintenant devenu un problème national, réclamant une action urgente, pour la sécurité des patients et la qualité des soins. Nous faisons remarquer qu'en 2011, aux États-Unis, la FDA avait identifié la gravité des pénuries de médicaments et l'impact que ces dernières avaient sur les soins aux patients et avait pris des mesures concrètes. ${ }^{\mathrm{H}} \mathrm{La}$ gravité croissante des pénuries de médicaments a conduit le président des États-Unis, Barack Obama, à signer un décret-loi pour veiller à ce que la population des États-Unis soit protégée contre une pénurie de médicaments sur ordonnance. ${ }^{\mathrm{I}}$ Il ne semble pas que des mesures comparables aient été prises au Canada. Plusieurs nuances doivent être apportées à ce propos. Il existe, par exemple, aux États-Unis un « marché gris » sur lequel il est possible d'obtenir des médicaments en pénurie ${ }^{\mathrm{J}}$ (moyennant souvent un prix plus

\footnotetext{
G http://www.pharmacists.ca/cpha-ca/assets/File/cpha-on-the-issues/ DrugShortagesReport.pdf (accessed March 2012).

${ }^{\mathrm{H}}$ http://www.fda.gov/downloads/AboutFDA/ReportsManualsForms/ Reports/UCM277755.pdf (accessed March 2012).

${ }^{\text {I }}$ http://www.whitehouse.gov/the-press-office/2011/10/31/executiveorder-reducing-prescription-drug-shortages (accessed March 2012).

J https://www.premierinc.com/about/news/11-aug/Gray-Market/GrayMarket-Analysis-08152011.pdf (accessed March 2012).
} 
élevé). ${ }^{\mathrm{K}}$ Considérant que le Canada va maintenant devoir importer des médicaments pour répondre aux besoins du marché, il est important de connaître les procédures réglementaires que Santé Canada appliquera pour garantir la qualité des médicaments importés, notamment en matière de stérilité, d'étiquetage et de formulation des médicaments. Santé Canada peut-il mettre en œuvre ces procédures de façon accélérée et à quel prix? Le ministère fédéral de la santé a indiqué que l'approvisionnement en médicaments essentiels pouvait être accéléré sans mettre les Canadiens en danger. ${ }^{\mathrm{L}}$

Si tel est le cas, cela revient à la question de savoir pourquoi une procédure de révision accélérée pour les demandes de médicaments brevetés n'a pas été mise en œuvre avant la pénurie actuelle de médicaments. Avec une pénurie de médicaments, à la fois nationale et internationale, de cette amplitude en vue, il est peu probable qu'un seul fabricant aura la capacité d'augmenter ses lignes de production pour répondre à des besoins immédiats et à court terme. De notre point de vue, il est probable que cette situation pourrait durer jusqu'à 12 à 18 mois.

Au niveau provincial, cette crise de pénurie de médicaments fait apparaître la complexité de la gestion des médicaments sur ordonnance dans notre système de soins. Santé Canada réglemente les processus d'approbation et d'autorisation à la vente des médicaments; toutefois, c'est aux provinces que revient la responsabilité de financer la fourniture de soins à leurs résidents et c'est aux hôpitaux et aux régions sanitaires que revient la responsabilité de sélectionner quels médicaments, quelles technologies et quelles interventions seront fournis. La raison pour laquelle la pénurie actuelle de médicaments a entraîné l'annulation d'interventions chirurgicales dans certaines provinces est due à la vulnérabilité qu'il y a à dépendre de sources uniques de distribution.

La pression inexorable incitant à la mise en œuvre de procédures simplifiées et de limitation des coûts a poussé la plupart des provinces à adopter un modèle d'achat auprès d'une source unique afin de contrôler les dépenses de médicaments. Trois groupes d'achats fournissent des médicaments à plus de $90 \%$ des hôpitaux canadiens. ${ }^{\mathrm{M}} \mathrm{En}$ conséquence, la capacité à se procurer des médicaments manquants au niveau local est limitée dans le cas où la « seule source » de distribution serait dans l'impossibilité de les fournir. Cette préoccupation est aggravée par le fait

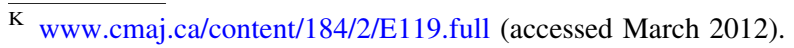

${ }^{\mathrm{L}}$ http://www.theglobeandmail.com/news/politics/government-fasttracks-approvals-for-vital-drugs/article2370988/ (accessed March 2012).

M Letter to The Deputy Minister of Health, Dated 2 March 2012, from MEDBUY (Richard Jones) and SigmaSanté (Jean-François Bussières).
}

que la plupart des distributeurs et pharmacies travaillent avec des modèles de livraison en flux tendu («juste à temps ») pour réduire les frais d'inventaire. Ceci signifie qu'il n'existait pas de stocks disponibles, provoquant les conséquences immédiates de la décision de Sandoz Canada.

La production et l'approvisionnement allégés (à flux tendus) sont devenus des substituts pour un «meilleur prix ». Tout en étant conscient des réalités fiscales actuelles auxquelles sont confrontés les soins de santé, il semble que la mise en œuvre de ces stratégies de réduction des coûts s'est fait aux dépens d'autres stratégies permettant d'assurer la fourniture continue de médicaments essentiels nécessaires à l'administration de soins modernes en anesthésie et aux soins intensifs. Signalons, entre parenthèses, que la majorité des médicaments employés en anesthésie sont relativement peu coûteux l'on peut se demander quelles économies ont été obtenues en adoptant des méthodologies de production/ livraison en flux tendu.

L'étendue de l'impact sur les soins aux patients canadiens de la pénurie actuelle en médicaments est inconnue, mais nous proposons quelques pistes de réflexion. Il y aura probablement une rationalisation et une priorisation de l'utilisation des médicaments au fur et à mesure que la pénurie s'aggravera, aboutissant à des annulations massives d'interventions chirurgicales. Les gouvernements provinciaux et fédéral devront élaborer des plans d'intervention pour permettre l'approvisionnement continu en produits pharmaceutiques pour répondre aux besoins de tous les Canadiens. Il y aura presque certainement des annulations d'interventions chirurgicales. Au mieux, cela constituera un désagrément et un allongement des listes d'attente et, au pire, les patients sur des plus longues listes d'attente pour une chirurgie risquent de décéder.

Nous encourageons tous les anesthésiologistes à accroître leur collaboration actuelle avec les pharmacies d'hôpitaux pour élaborer des directives transparentes pour la répartition des ressources médicamenteuses en quantités limitées. On pourrait envisager, par exemple, un schéma de priorisation dans lequel les urgences mettant en jeu le pronostic vital bénéficieraient d'une priorité absolue (les données historiques concernant les quantités et types de médicaments à stocker pour répondre à ces besoins devront être incluses), suivies par les chirurgies programmées nécessitées par une maladie mettant en danger la survie globale ou celle d'un membre, les chirurgies pour lesquelles la liste d'attente est (déjà) longue, etc. De plus, les produits fournis dans des conditionnements de grand volume (par exemple, le fentanyl fourni en flacons de $20 \mathrm{~mL}$ ) pourront être divisés en plus petites aliquotes (dans les conditions de stérilité appropriées) dans des seringues préremplies prêtes à l'emploi, ou des médicaments de substitution (comme le sufentanil) disponibles en plus 
grande quantité pourront être employés. Les médecins responsables doivent s'engager activement au niveau hospitalier, avec les régions sanitaires et les gouvernements provinciaux et fédéral, à travailler sur le modèle expliquant les raisons des interruptions d'approvisionnement pharmaceutique et à l'élaboration de plans d'urgence pour répondre à ces problèmes (comme au cours de la gestion récente de la pandémie $\mathrm{H} 1 \mathrm{~N} 1$ et de la crise de la pénurie de sang).

Il est essentiel que des mesures soient prises immédiatement pour pallier la pénurie actuelle de médicaments, non seulement en anesthésie et aux soins intensifs, mais aussi dans d'autres domaines thérapeutiques comme l'oncologie et les maladies infectieuses. De telles mesures peuvent inclure une législation obligeant les fabricants à adresser des avis appropriés sur toute menace de pénurie aux autorités fédérales et provinciales de façon à permettre la constitution de stocks et le recours à un plan d'intervention d'urgence. Des amendes devraient être imposées si ces mesures ne sont pas respectées. Dans le cas d'un désastre ou d'une interruption d'approvisionnement imprévisible, des moyens d'approvisionnement de secours en médicaments jugés indispensables doivent être disponibles. Tout en reconnaissant aux sociétés pharmaceutiques le droit de choisir les produits qu'elles développent et fabriquent, il faut admettre que certains médicaments (comme la morphine, l'éphédrine et la norépinéphrine) peuvent ne pas être profitables mais sont néanmoins essentiels à la santé des Canadiens. Des solutions permettant d'assurer l'approvisionnement ininterrompu de tous les médicaments essentiels sont facilement imaginées.

De plus, il est impératif que les grands groupes d'achat ne soient plus autorisés à passer des contrats d'exclusivité («source unique») pour l'approvisionnement en médicaments essentiels, éliminant de ce fait la possibilité pour de plus petites entreprises concurrentes de rester sur le marché. Par nécessité, ces sociétés vont maintenant alimenter une part du marché et, de notre point de vue, elles devraient être encouragées à le faire et à continuer à le faire. Une disposition législative doit être mise en place pour inciter les petites entreprises à continuer à rester concurrentes sur le marché canadien, et pour éliminer la clause de contrat d'exclusivité pour les médicaments essentiels, quelle qu'en soit la définition.

En conclusion, quand on examine la capacité du système de soins canadien à assurer efficacement les soins des Canadiens, on voit qu'un certain nombre de points importants doivent être réexaminés, notamment la responsabilité de l'industrie pharmaceutique et des grands groupes d'achat à assurer un approvisionnement continu en médicaments, la pratique de l'approvisionnement des pharmacies en flux tendu, la place d'un plan d'intervention pour les médicaments et du stockage des médicaments, enfin la pratique d'attribution de contrats exclusifs de source unique. Selon nous, ce désastre était totalement évitable. Les Canadiens méritent une meilleure gestion de notre système d'approvisionnement en médicaments. 